\title{
Effect of inoculum density of Stromatinia cepivora on the amount of white rot reduced by Trichoderma species in garlic
}

\author{
I. E. Elshahawy*, Nehal Saied, F. Abd-El-Kareem and A. Morsy
}

\begin{abstract}
Background: White rot, a garlic disease caused by the soil-borne fungus Stromatinia cepivora (Berk.) Whetzel, is a serious problem of garlic productions in Egypt. This study examines the potential of controlling the disease biologically by using three Trichoderma species, i.e., Trichoderma harzianum, Trichoderma koningii, and Trichoderma virens employed either alone or in combination.
\end{abstract}

Results: In in vitro assays, three Trichoderma species, i.e., Trichoderma harzianum, Trichoderma koningii, and Trichoderma virens and tebuconazole, were compared for their ability to suppress S. cepivora isolate (Sc8). In greenhouse experiments, the chemical treatment was the most effective, with the lowest incidence of garlic white rot compared with the control. The antagonistic fungi tested either individually or in combination significantly reduced the incidence of white rot on garlic. In general, dual and triple combinations of the fungal isolates were more effective than these isolates used individually. The combination of the three Trichoderma species was the most effective treatment, decreasing disease incidence by 50.0\% in 2016/2017 season and 40.0\% in 2017/2018 season, respectively. The three Trichoderma species employed alone or in combinations and tebuconazole were evaluated under low and high disease pressures in field trials to determine which situation (s) provided the best control of garlic white rot. Under low (40 sclerotia/kg of soil) and high (600 sclerotia/kg of soil) inoculum density, the standard fungicide programme (dipping of garlic cloves in tebuconazole $(1 \mathrm{ml}$ of Folicur $25 \% \mathrm{I}^{-1}$ of water) plus spraying garlic stem bases with the same concentration of tebuconazole) gave statistically significant disease control, decreasing disease incidence by 67.7 and 29.4\% in 2016/2017 season and 72.6 and 31 . $1 \%$ in 2017/2018 season, respectively. Under low disease pressure, significant control, equal to the fungicide treatment, was achieved with the trip combination of three Trichoderma species. However, Trichoderma species employed alone gave insignificant control of garlic white rot under high disease pressure. The triple combination of three Trichoderma species decreasing disease incidence by 65.6 and 15.5\% in 2016/2017 season and 74.2 and 18.6\% during 2017/2018 season, under low and high inoculum density, respectively. The activities of defense enzymes, i.e., peroxidase, polyphenoloxidase, and chitinase due to application of Trichoderma species, were enhanced in garlic plants either grown under low or high disease pressures. Reduction of white rot disease incidence was accompanied by increased growth parameters and bulbs yield of garlic plants grown under field conditions.

Conclusions: These results indicated that the performance of three Trichoderma species may be influenced as much by the absolute disease pressure. It was concluded that, at the low disease pressure site, the low level of inoculum and disease incidence enabled three Trichoderma species to bring about disease control.

Keywords: Garlic, White rot, Disease pressure, Three Trichoderma species

\footnotetext{
* Correspondence: ibrahim_nrc@yahoo.com

Plant Pathology Department, Agricultural and Biological Research Division,

National Research Centre, Giza, Egypt
} 


\section{Background}

Garlic (Allium sativum L.) is a monocotyledonous plant that belongs to the family Alliaceae. It is the second most widely cultivated vegetable next to onion and widely produced for its medicinal and nutritional properties. The annual world garlic production is about 22.2 million tons (Palmero et al. 2013). In 2016, Egypt produced approximately 247,000 metric tons garlic from 10,473 ha (Anonymous 2017). Unfortunately, in Egypt and several other countries, garlic is liable to infection by several soil-borne fungi which affected on both quantity and quality of the cloves after harvest (Elshahawy et al. 2017a). White rot disease caused by the soil-borne pathogen Stromatinia cepivora (Berk.) Whetzel is one of the most important and destructive diseases of garlic and prevalent worldwide (Pinto et al. 2000; Coventry et al. 2002; Ulacio-Osorio et al. 2006; Tamire et al. 2007; Zeray and Mohammed 2013; Dilbo et al. 2015). The first indication of white rot infection is a change in leaf color from bright green to blue green. The outer leaves of the garlic then change to a yellowish color and begin to die back from the tips. Subsequently, the whole plant wilts and dies. Below ground, the roots are gradually destroyed, enabling the plant to be easily pulled from the soil. $S$. cepivora also causes a semi-watery decay of the scales which is associated with the growth of superficial white mycelium on the affected area (Abd El-Razik et al. 1973). Within several days, the mycelium darkens and is transformed into large numbers of sclerotia (Abd El-Razik et al. 1973). Plant decay and harvesting procedures result in the release of sclerotia into the soil. Sclerotia are the only reproductive structures of $S$. cepivora as no perfect stage has yet been described (Coley-Smith 1990; Crowe 1995) and no asexual spores are produced. The sclerotia are black, uniformly round, and are $200-500 \mu \mathrm{m}$ in diameter (Coley-Smith 1960). A narrow, smooth, or pitted rind surrounds a medulla of compact interwoven hyphae and a gelatinous material is often present in the interhyphal spaces (Coley-Smith 1960). The protective nature of the sclerotial rind enables the sclerotia to remain viable in the soil for a substantial length of time reached to 20 years (Coley-Smith 1990). The sclerotia are stimulated to germinate only by Allium-specific root exudates, making the disease highly specific to Allium species. The disease has been found in every country where Allium species are cultivated (Stewart and McLean 2007), and to date no system of control has been shown to fully prevent the occurrence of the disease. As the disease became increasingly widespread and persistent, the control of garlic white rot by fungicides became almost exclusive. Successful control of white rot was obtained after the introduction of systemic fungicides. The dicarboximides, iprodione and vinclozolin, were highly effective in controlling white rot disease in New Zealand (Wood 1980). In the UK, iprodione was used as a seed and stem treatments (Entwistle and Munasinghe 1980). Unfortunately, in both the UK and New Zealand, the continued use of iprodione and vinclozolin had led to a decrease in effectiveness that was due to enhanced degradation of the chemicals by soil microorganisms (Entwistle 1983; Walker et al. 1986; Slade et al. 1992). However, concerns associated with environmental impacts of such fungicidal chemicals, the increasing development as well as registration costs, and the reduction of fungicide effectiveness were due to the resistance and enhanced microbial degradation, which called for alternative control measures include use of beneficial microorganisms (Entwistle 1992). A number of fungal species had been identified with potential as biological control agents of white rot disease (Utkhede and Rahe 1980; Abd-El-Moity and Shatla 1981; De Oliveira et al. 1984; Harrison and Stewart 1988; Kay and Stewart 1994; McLean and Stewart 2000; El-Khateeb 2004; McLean et al. 2005; McLean et al. 2012; Shalaby et al. 2013; Elshahawy et al. 2017b, c; Elshahawy et al. 2018). In previous study, the fungal isolates Trichoderma harzianum, Trichoderma koningii, and Trichoderma virens were confirmed as antagonists of Stromatinia cepivora isolate (Sc2), the most pathogenic isolate of onion and garlic white rot (Elshahawy et al. 2017b). We also found that in dual culture with S. cepivora, these isolates produced inhibition zones and colonized pathogen hyphae. When agar was amended with culture filtrates of each of $T$. harzianum, T. koningii, and T. virens, the growth of $S$. cepivora was distorted or unusual, indicating the production of antibiotics (Elshahawy et al. 2017b). This paper reports the results of tow field trials which compared the standard fungicide programme for garlic white rot with solid substrate formulations of T. harzianum, T. koningii, and $T$. virens employed either alone or in combination applied at sowing under varying disease pressures.

\section{Methods \\ Garlic white rot pathogen}

One isolate of S. cepivora ( $\mathrm{Sc} 8$ ) was obtained from the author's collection. This isolate was found to be of high virulence against garlic based on pathogenicity tests conducted in previous studies (Elshahawy et al. 2018).

\section{Trichoderma species}

Three identified fungal antagonists including Trichoderma harzianum, Trichoderma koningii, and Trichoderma virens were obtained from Plant Pathology Department, NRC. Identification of Trichoderma species were re-confirmed according to a taxonomic key for the genus Trichoderma (Rifai 1969; Watanabe 1994).

Testing the antagonistic activity of Trichoderma species Each of the T. harzianum, T. koningii, and T. virens was tested for antagonism for S. cepivora (Sc8) using the dual 
culture techniques (Bell et al. 1982). PDA plates were inoculated on one side with a 5-mm mycelial disk from a 7-day-old culture of the test fungus. The opposite side was inoculated with a disc of S. cepivora ( $\mathrm{Sc} 8)$ and the plates were incubated at $18 \pm 2{ }^{\circ} \mathrm{C}$ in the dark. Four replicate plates were inoculated for each test fungus. After 14 days, the following parameters were measured: (i) average colony radius and percentages of growth reduction and (ii) average number of sclerotia per $\mathrm{cm}^{2}$ and percentages of reduction. Tebuconazole (commercialized as Folicur ${ }^{\circ}, 25 \%$ a.i. Bayer Group Science, Germany) was used in the above experiments for comparison. The chemical treatment was applied at the recommended rate $1.0 \mathrm{ml}$ Folicur $/ \mathrm{L}$.

Inhibitor effect of cultural filtrate to sclerotial germination Sclerotia were collected from S. cepivora (Sc8) cultures (60-day-old) and soaked in test tubes containing the culture filtrate of each of the Trichoderma species to be tested for $12 \mathrm{~h}$ at room temperature. At end of the soaking period, sclerotia were washed with sterile distilled water and 30 sclerotia from each treatment were transferred individually under aseptic conditions to Petri dishes containing PDA. Water-soaked sclerotia were used as the control treatment. Four replicates (dishes) were used for each treatment. Petri dishes bearing sclerotia were incubated at $18-20{ }^{\circ} \mathrm{C}$ for 7 days and percentages of germinating sclerotia were determined. Tebuconazole was used at the rate of $1.0 \mathrm{ml}$ Folicur/L for comparison.

\section{Greenhouse experiments}

\section{Preparation of Trichoderma species inocula}

$T$. harzianum, $T$. koningii, and $T$. virens used in this study were grown on sterilized $\left(121{ }^{\circ} \mathrm{C}\right.$ for $\left.60 \mathrm{~min}\right)$ wheat bran as a carrier preparation (Mahdizadehnaraghi et al. 2015). Carboxymethyl cellulose (1\%) was used as an adhesive at the rate of $1: 10(\mathrm{v} / \mathrm{w})$. The $\mathrm{pH}$ was adjusted to neutral by adding $\mathrm{CaCO}_{3}$ at the rate of $15 \mathrm{~g} /$ $\mathrm{kg}$. Then, $3 \%$ mannitol was added as osmoticant at the rate of $8.5 \mathrm{ml}$ for $100 \mathrm{~g}$ formulation. Spore suspension $\left(10^{6}\right.$ spores $\left./ \mathrm{ml}\right)$ of each of T. harzianum, T. koningii, and $T$. virens were incorporated into sterilized wheat bran under aseptic conditions at the rate of $50 \mathrm{ml}$ of suspension per $100 \mathrm{~g}$ and thoroughly mixed with a sterilized spoon. Subsequently, each of Trichoderma spp. spore suspension $\left(10^{6}\right.$ spores $\left./ \mathrm{ml}\right)$ was individually incorporated into sterilized wheat bran carrier under aseptic conditions at the rate of $50 \mathrm{ml}$ of suspension per $100 \mathrm{~g}$ and thoroughly mixed with the help of sterilized spoon. The materials (35\% moisture content) were packed in polythene bags, sealed, and stored at room temperature. These formulations used alone or their dual and triple combinations (equal volumes of each) were applied in the greenhouse and field experiments.

\section{Preparations of garlic white rot pathogen inocula}

Fungal mass of garlic isolate S. cepivora (Sc8) for soil infestation in greenhouse experiments was obtained by growing the isolate on a sand-barley medium (Abd El-Moity 1976). This medium was prepared by mixing $50 \mathrm{~g}$ barley grains, $50 \mathrm{~g}$ sand, and $40 \mathrm{ml}$ water; then the mixture in glass bottles ( $500 \mathrm{ml}$ capacity) with cotton plugs was sterilized at $121{ }^{\circ} \mathrm{C}$ for $30 \mathrm{~min}$. The autoclaved medium was inoculated with a $5 \mathrm{~mm}$ disk of S. cepivora (Sc8) and incubated at $18 \pm 2{ }^{\circ} \mathrm{C}$ for 5 weeks.

\section{Effects of Trichoderma species on garlic white rot disease development}

The effects of the three Trichoderma species, i.e., $T$. harzianum, T. koningii, and T. virens and their combinations (equal volumes of each) were investigated on the development of white rot disease on garlic in soil artificially infested with $S$. cepivora $(\mathrm{Sc} 8)$. The experiment was carried out in pots under greenhouse conditions (the minimum and the maximum temperatures were $5-10{ }^{\circ} \mathrm{C}$ and $20-25{ }^{\circ} \mathrm{C}$, respectively) using susceptible cultivar of garlic as in El-Sheshtawi et al. (2009). The experiments were conducted with a completely randomized design (CRD) with nine treatments (seven of the three selected Trichoderma species and their combinations of T. harzianum (Th), T. koningii (Tk) and T. virens $(\mathrm{Tv}), \mathrm{Th}+\mathrm{Tk}, \mathrm{Th}+\mathrm{Tv}, \mathrm{Tk}+\mathrm{Tv}, \mathrm{Th}+\mathrm{Tk}$ $+\mathrm{Tv}$, bioformulated on wheat bran previously described, chemical fungicide, and infected control) each with four replicates. Each replicate consisted of a sterilized plastic pot (30 cm diameter) containing $5 \mathrm{~kg}$ of autoclaved loamy clay soil pre-infested with $S$. cepivora (Sc8) at the rate of $2 \%(w / w) 2$ weeks before sowing. The formulated Trichoderma species were added (at the rate of $1 \% w / w$ ) to the infested soil one week before planting. The chemical treatment was applied according to the standard fungicide programme (garlic cloves dipped in $1.0 \mathrm{ml}$ Folicur plus foliar spray). The chemical treatment was applied according to the standard fungicide programme. In this programme, garlic cloves were dipped and sprayed (two time intervals 6 weeks in between) with $1 \mathrm{ml} / \mathrm{L}$ Folicur. Before chemical treatment, cloves were superficially disinfected by dipping in sodium hypochlorite solution $(0.25 \%)$ for 2 min and rinsed after surface-sterilization with sterile distilled water. Five surface disinfected garlic cloves (cv. Sides 40) were sown in each pot. Nitrogen fertilizer as urea $(46 \% \mathrm{~N})$ was added at the rate of $10 \mathrm{~g} /$ pot 30 days after planting and plants were irrigated when necessary. The percentages of disease incidence were calculated after 100 days after planting as follows: disease incidence $(\%)=100 \times$ No. of infected plants/No. of total plants (Zewide et al. 2007). 


\section{Field experiments}

\section{Selection of trials location}

Field trials were conducted in El-Deer village, El-Qalubia governorate, whereas white rot disease was of high commercial interest. In this region, several fields with a well-established history of white rot disease were selected preliminarily for inoculum density determinations according to the procedure of Utkhede and Rahe (1979). After that, two field sites were chosen. One of them was characterized by their low sclerotial density and had 40 sclerotia per $1 \mathrm{~kg}$ soil. The second was characterized by high sclerotial density and had an average of 600 sclerotia per $1 \mathrm{~kg}$ soil.

\section{Effects of Trichoderma species on garlic white rot disease development}

Two field trials were used to estimate the efficiency of the three selected Trichoderma species and their combinations for controlling white rot disease of garlic plants. The low sclerotial density trial had an average of 40 sclerotia per $1 \mathrm{~kg}$ soil and the high sclerotial density second trial had 600 sclerotia per $1 \mathrm{~kg}$ soil. For each trial, the experiments were conducted with a completely randomized design (CRD) with nine treatments (seven of the three selected Trichoderma species and their combinations of $T$. harzianum (Th), $T$. koningii (Tk) and $T$. virens $(\mathrm{Tv}), \mathrm{Th}+\mathrm{Tk}, \mathrm{Th}+\mathrm{Tv}, \mathrm{Tk}+\mathrm{Tv}, \mathrm{Th}+\mathrm{Tk}+\mathrm{Tv}$, bioformulated on wheat bran previously described, chemical fungicide, and control) each with four replicates plots. The plot area was $3.0 \times 3.5 \mathrm{~m}\left(10.5 \mathrm{~m}^{2}\right)$ each plot included six rows (each $3.0 \mathrm{~m}$ length and $50 \mathrm{~cm}$ width). Each treatment preparation freshly prepared was incorporated to soil at the rate of $300 \mathrm{~g}$ formulation $/ \mathrm{m}$ length of the row. A cavity $15-\mathrm{cm}$ in depth was made in the surface of each row. Then the powder preparation of each treatment was added to this cavity and then recovered with the soil and immediately irrigated. One week after incorporation, surface-disinfected garlic cloves (cv. Sides 40) were planted in each row. Garlic cloves that had been uniformly sized were hand planted 3-in deep in rows spaced $10 \mathrm{~cm} \times 10 \mathrm{~cm}$ within each row. Based on garlic production regimes, the plots were planted with garlic cloves on 15-September of 2016 of 2016/ 2017 growing season and the experiment was repeated in 2017/2018 growing season. The chemical treatment was applied by dipping garlic cloves before sowing in fungicide formulation $(1.0 \mathrm{ml}$ Folicur/L) for $5 \mathrm{~min}$. One month later, stem bases of garlic plants were sprayed (tow times) with the same concentration of Folicur at 6-week intervals. Irrigation and fertilization for garlic were conducted with commercial production in the area. White rot disease evaluations were conducted periodically during the growing season based on top symptoms of white rot, and were confirmed by gently removing some soil from around the base of some plants. At harvest, bulbs with symptoms of white rot were assessed by pulling and observing all garlic bulbs in each plot. The percentage of infected plants as well as white rot reduction (\%) was calculated according to Hovius and McDonald (2002) as follows:

$$
\begin{aligned}
& \text { White rot infection (\%) } \frac{\text { No of infected plants with white rot }}{\text { Total no.of plants }} \times 100 \\
& \text { White rot reduction (\%) } \frac{\text { White rot (\%) in control-White rot (\%) in treatment }}{\text { White rot (\%) in control }} \\
& \qquad \times 100
\end{aligned}
$$

\section{Effect of Trichoderma species on enzymatic activities in garlic plants}

The effect of T. harzianum, T. koningii, T. virens alone, and their dual and triple combinations on the activities of the defense enzymes of peroxidase, polyphenoloxidase, and chitinase of garlic plants was estimated at 100 days after planting. To extract the enzyme, garlic-leave samples (g) were homogenized with $0.2 \mathrm{M}$ Tris $\mathrm{HCl}$ buffer $(\mathrm{pH}$ 7.8) at $0{ }^{\circ} \mathrm{C}$ containing $14 \mathrm{~m} \mathrm{M} \mathrm{B-mercaptoethanol} \mathrm{at} \mathrm{the}$ rate of $1 / 3 \mathrm{w} / v$. The extracts were obtained by filtering off the debris with a clean cloth and centrifuging at $3000 \mathrm{rpm}$ for $15 \mathrm{~min}$. The supernatants were recovered and kept in a tube in an ice bath until assayed. The supernatant was used to determine the activity of enzymes using UV spectrophotometer. Peroxidase activity was assayed with guaiacol as the hydrogen donor as described by Hammerschmidt et al. (1984) and peroxidase activity was expressed as the increase in absorbance at $470 \mathrm{~nm} / \mathrm{g}$ fresh weight/minute according to the method described by Lee (1973). Polyphenoloxidase enzyme activity was determined by measuring the rate of quinone formation as a result of oxidizing 3,4-dihydroxyphenylalanine (DOPA) and polyphenoloxidase activity was expressed as the increase in absorbance at $475 \mathrm{~nm} / \mathrm{g}$ fresh weight/minute according to the method described by Bashan et al. (1985). The determination of chitinase enzyme was carried out using colloidal chitin as substrate and dinitrosalicylic acid (DNS) as reagent to measure reducing sugars according the method described by Monreal and Reese (1969). Chitinase activity was expressed as $\mathrm{mM} N$-acetylglucose amine equivalent released/gram fresh weight/60 min at $450 \mathrm{~nm}$.

\section{Effect of Trichoderma species on plant growth and bulb yield}

Effects of $T$. harzianum (Th), $T$. koningii (Tk), and $T$. virens (Tv) on plant growth were studied on onion and garlic grown under field conditions. The isolates alone and their dual and triple combinations and chemical fungicide were applied as described in field experiments. Four replicates were used per treatment. Negative control plots were treated with wheat bran free of antagonistic fungi. At 100 days after planting, some vegetative 
growth parameters: average plant height $(\mathrm{cm})$, average number of leaves/plant, and average plant biomass (g), of each crop was estimated. At the end of the experiment (180 days for garlic after planting), fresh weight of garlic plants (bulbs with the tops of the plants) within each plot were weighed. Efficacy of treatments was calculated using the following formula: efficacy $(\%)=$ fresh weight of plants in control - fresh weight of plants in treatment / fresh weight of plants in control $\times 100$.

\section{Statistical analysis}

Data were entered into SPSS software version 14.0 and analyzed statistically by the analysis of variance (ANOVA) test and the means were compared by Duncan's multiple range test at $P<0.05$. Data collected from field experiments were analyzed separately for each growing season. Data for percentage germinated sclerotia and percent data on disease incidence were statistically analyzed after arcsine square-root transformation; however, untransformed data are presented.

\section{Results}

Laboratory experiments

Antagonistic activity

Three antagonistic fungi, i.e., T. harzianum, T. koningii, T. virens, and tebuconazole, were compared for their ability to suppress S. cepivora (Sc8). Data presented in Table 1 indicated that the chemical treatment of tebuconazole inhibited both of the growth and sclerotial formation of $S$. cepivora (Sc8). All Trichoderma species isolates significantly inhibited the growth of S. cepivora (Sc8) in dual culture compared to control (Fig. 1). The inhibition in the growth and sclerotial formation of $S$. cepivora caused by T. harzianum, T. koningii, and T. virens was 90.4; 76.3, 91.2; 51.9 , and $86.8 ; 60.6 \%$, respectively.

\section{Inhibitor effect of cultural filtrate to sclerotial germination} The three Trichoderma species cultural filtrates decreased S. cepivora sclerotial germination after soaking for $12 \mathrm{~h}$ (Table 2). T. koningii filtrate caused the greatest reduction (79.3\%) in sclerotial germination, followed by T. harzianum filtrate (70.5\%). T. virens culture filtrate caused the least reduction (67.9\%). In the same trend, the chemical treatment with tebuconazole inhibited the sclerotial germination of $S$. cepivora completely after soaking for $12 \mathrm{~h}$.

\section{Greenhouse experiments}

Data presented in Table 3 showed that the treatments significantly reduced the incidence of garlic plant during 2016/2017and 2017/2018 seasons. Trichoderma species (either individually or in combination) significantly reduced the incidence of white rot on garlic. In general, dual and triple combinations of Trichoderma isolates were more effective than these isolates used individually. The combination of all three Trichoderma species was the most effective treatment. The rates of decreasing disease incidence were 50.0 and $60.0 \%$ during 2016/ 2017and 2017/2018 seasons.

\section{Field experiments}

Results of the two growing seasons followed the same trends. The amount of white rot was related to inoculum density. The mean disease incidence of S. cepivora infection among garlic plants in soil containing 40 sclerotia/ $\mathrm{kg}$ of soil were significantly less than in those containing 600 sclerotia/kg of soil. In general, the Trichoderma isolates were more effective in reducing white rot disease in the trial with low inoculum density than in high inoculum density. In the low inoculum density trial, the chemical treatment was the most effective, with the lowest disease incidence $(7.75 \%$ in $2016 / 2017$ season and $13.0 \%$ in $2017 / 2018$ season), compared with 24.0 and $47.5 \%$ for the control, respectively as shown in Table 4. In general, the dual and triple combinations of the tested Trichoderma isolates were more effective than these isolates used individually. The combination of all three Trichoderma isolates was the most effective treatment, decreasing disease incidence by $65.6 \%$ and $74.2 \%$ during 2016/2017and 2017/2018 seasons. In the high inoculum

Table 1 Growth area $\left(\mathrm{cm}^{2}\right)$ and number of sclerotia/ $\mathrm{cm}^{2}$ of Stromatinia cepivora isolate (Sc8) in dual culture with Trichoderma species as well as in tebuconazole and control

\begin{tabular}{lllll}
\hline Treatment & Growth area $\left(\mathrm{cm}^{2}\right)^{\mathrm{a}}$ & Reduction (\%) & No. of sclerotia in $\left(\mathrm{cm}^{2}\right)$ & Reduction $(\%)$ \\
\hline T. harzianum & $06.75 \pm 0.14 \mathrm{c}^{\mathrm{a}}$ & 90.4 & $19.00 \pm 1.00 \mathrm{~d}$ & 76.3 \\
T. koningii & $06.13 \pm 0.13 \mathrm{c}$ & 91.2 & $38.50 \pm 0.50 \mathrm{~b}$ & 51.9 \\
T. virens $_{\text {Tebuconazole }}^{\mathrm{b}}$ & $09.25 \pm 0.48 \mathrm{~b}$ & 86.8 & $31.50 \pm 0.87 \mathrm{c}$ & 60.6 \\
Control & $00.00 \pm 0.00 \mathrm{~d}$ & 100.0 & $00.00 \pm 0.00 \mathrm{e}$ & 100.0 \\
\hline
\end{tabular}

Values are mean of four replicates for each treatment as well as the control

Means \pm standard error within a column followed by the same letter are not significantly

different by Duncan multiple range test at $P<0.05$

${ }^{a}$ Growth area $\left(\mathrm{cm}^{2}\right)$ of $S$. cepivora was calculated using a planimeter

${ }^{\mathrm{b}}$ The fungicide tebuconazole was used at the recommended dose of $1 \mathrm{ml}$ Folicur/L 


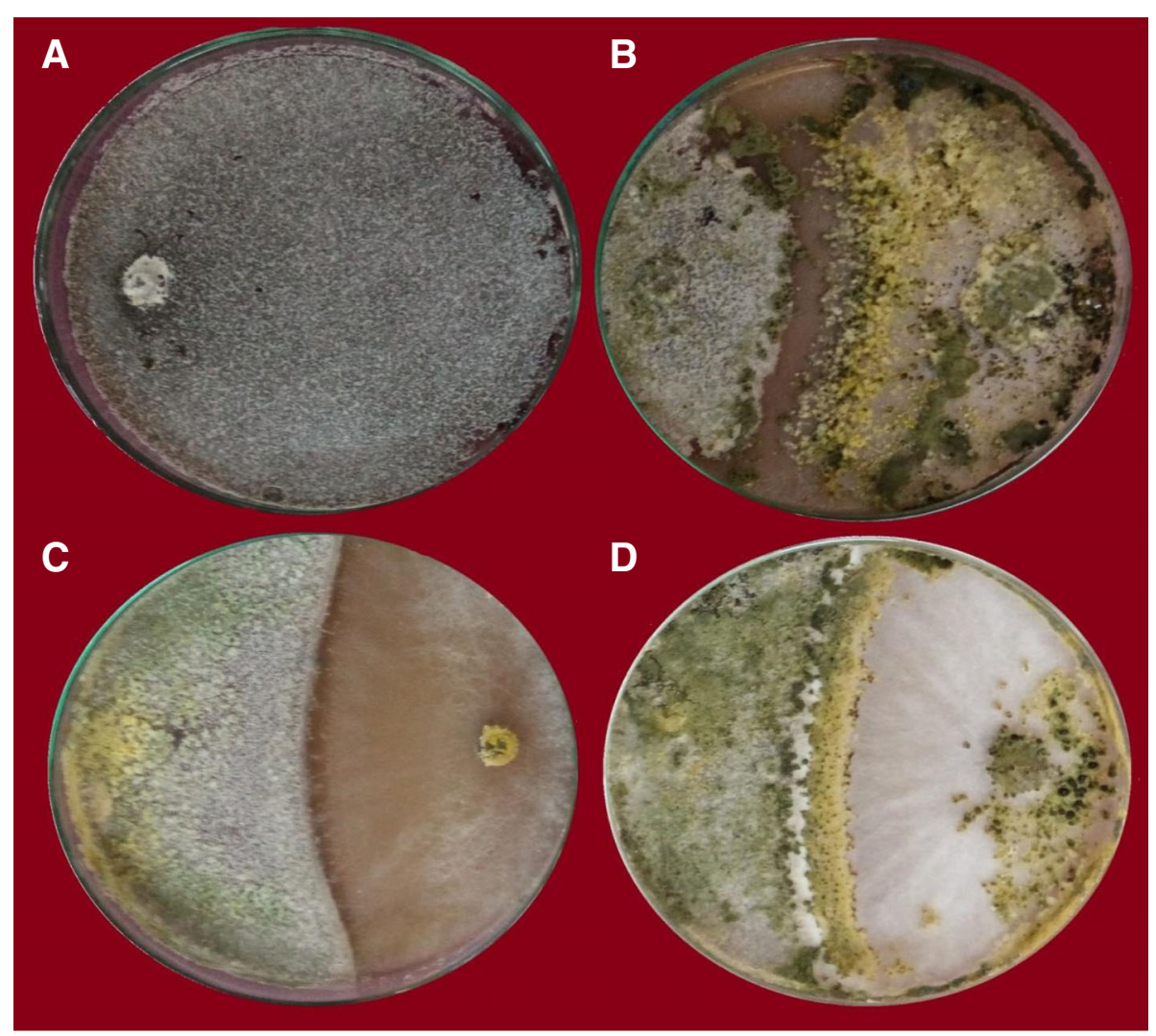

Fig. 1 Antagonistic effect of Trichoderma species on Stromatinia cepivora growth. a Stromatinia cepivora alone (control), b Stromatinia cepivora in the presence of T. harzianum, c S. cepivora in the presence of T. koningii, and $\mathbf{d} S$. cepivora in the presence of T. virens

density trial, no Trichoderma isolates employed alone gave significant control of garlic white rot. In general, the dual and triple combinations of the tested Trichoderma isolates give significant white rot control than these isolates used individually. The combination of all three Trichoderma isolates was the most effective treatment, decreasing disease incidence by $15.5 \%$ in $2016 / 2017$ season and $18.6 \%$ in $2017 / 2018$ season.

Table 2 Sclerotial germination (\%) of S. cepivora isolate (Sc8) after soaking in cultural filtrates of Trichoderma strains as well as chemical fungicide in vitro

\begin{tabular}{lll}
\hline Treatment & $\begin{array}{l}\text { Sclerotial } \\
\text { germination (\%) }\end{array}$ & $\begin{array}{l}\text { Reduction } \\
(\%)\end{array}$ \\
\hline T. harzianum & $28.5 \pm 0.96 \mathrm{~b}^{\mathrm{a}}$ & 70.5 \\
T. koningii & $20.0 \pm 0.71 \mathrm{c}$ & 79.3 \\
T. virens & $31.0 \pm 1.22 \mathrm{~b}$ & 67.9 \\
Tebuconazole & $00.0 \pm 0.00 \mathrm{~d}$ & 100.0 \\
Water (negative control) & $96.7 \pm 1.36 \mathrm{a}$ & - \\
\hline
\end{tabular}

Values are mean of four replicates for each treatment as well as the control ${ }^{a}$ Means \pm standard errors within a column followed by the same letter are not significantly different by Duncan multiple range test at $P<0.05$ ${ }^{\mathrm{b}}$ The fungicide tebuconazole was used at the recommended dose of $1 \mathrm{ml}$ Folicur/L

\section{Effects on enzymatic activities in garlic plants}

Results of the two trails followed the same trends. The tested antagonistic fungi used either individually or in combinations were pronounced in induction of defense enzyme in comparison with the control. In general, the dual and triple combinations were more effective than using these isolates individually (Table 5). The triple combination of all three Trichoderma species was the most effective treatment, induced high activation of peroxidase, polyphenoloxidase, and chitinase by $75.0 ; 72.3,61.5 ; 63.7$, and $62.3 ; 70.8 \%$ increase over control, under low and high inoculum density, respectively.

\section{Effect of the Trichoderma isolates on plant growth and bulb yield in the field}

The Trichoderma isolates and their combinations significantly affected plant growth of garlic cv. Sides 40 during two field trials (Table 6). Results of the two trials followed the same trends but the amount of growth improvements was related to inoculum density. The mean growth parameters among plants in soil containing 40 sclerotia $/ \mathrm{kg}$ were significantly greater than in soil containing 600 sclerotia $/ \mathrm{kg}$ of soil. In general, the Trichoderma isolates were more effective in improving onion and garlic growth in 
Table 3 Effects on white rot incidence (\%) in garlic under greenhouse conditions

\begin{tabular}{|c|c|c|c|c|}
\hline \multirow[t]{3}{*}{ Treatment } & \multicolumn{4}{|c|}{ White rot incidence (\%) and reduction (\%) } \\
\hline & \multicolumn{2}{|c|}{ 2016/2017 season } & \multicolumn{2}{|c|}{$2017 / 2018$ season } \\
\hline & Incidence (\%) & Reduction (\%) & Incidence (\%) & Reduction (\%) \\
\hline T. harzianum (Th) & $80.0 \pm 0.00 b^{a}$ & 20.0 & $85.0 \pm 5.00 \mathrm{~b}$ & 15.0 \\
\hline T. koningii (Tk) & $80.0 \pm 0.00 \mathrm{~b}$ & 20.0 & $75.0 \pm 5.00 \mathrm{bc}$ & 25.0 \\
\hline T. virens (Tv) & $80.0 \pm 0.00 \mathrm{~b}$ & 20.0 & $75.0 \pm 5.00 \mathrm{bc}$ & 25.0 \\
\hline$(T h)+(T k)$ & $70.0 \pm 5.77 b$ & 30.0 & $75.0 \pm 5.00 \mathrm{bc}$ & 25.0 \\
\hline$(T h)+(T v)$ & $70.0 \pm 5.77 b$ & 30.0 & $70.0 \pm 5.77 \mathrm{~cd}$ & 30.0 \\
\hline$(T k)+(T v)$ & $70.0 \pm 5.77 b$ & 30.0 & $70.0 \pm 5.77 \mathrm{~cd}$ & 30.0 \\
\hline$(T h)+(T k)+(T V)$ & $50.0 \pm 5.77 \mathrm{c}$ & 50.0 & $60.0 \pm 0.00 d$ & 40.0 \\
\hline Tebuconazole & $20.0 \pm 0.00 \mathrm{~d}$ & 80.0 & $30.0 \pm 5.77 \mathrm{e}$ & 70.0 \\
\hline Control & $100.0 \pm 0.00 \mathrm{a}$ & - & $100.0 \pm 0.00 \mathrm{a}$ & - \\
\hline
\end{tabular}

Values are mean of five replicates for each treatment as well as the control

${ }^{a}$ Means \pm standard errors within a column followed by the same letter are not significantly different by Duncan multiple range test at $P<0.05$

the trial with low inoculum density compared with the trial with high inoculum density. In the low inoculums density trial, the triple combinations of the tested Trichoderma isolates were the most effective. The increase rates of plant growth parameters (plant height, number of leaves/plant biomass) were $27.1,33.0$, and $42.1 \%$, respectively compared with the control (Table 6). The effects on garlic grown in soil with high inoculum density followed the same trend (Table 6). The effects of soil application with Trichoderma isolates and their combinations on garlic bulb yield at two

Table 4 Effects on white rot disease incidence (\%) in garlic under field conditions

\begin{tabular}{|c|c|c|c|c|}
\hline \multirow[t]{3}{*}{ Treatment } & \multicolumn{4}{|c|}{ White rot incidence (\%) and reduction (\%) } \\
\hline & Incidence (\%) & Reduction (\%) & Incidence (\%) & Reduction (\%) \\
\hline & \multicolumn{2}{|l|}{$\begin{array}{l}\text { Trial I ( } 40 \\
\text { sclerotia/kg soil) }\end{array}$} & \multicolumn{2}{|l|}{$\begin{array}{l}\text { Trial II (600 } \\
\text { sclerotia/kg soil) }\end{array}$} \\
\hline \multicolumn{5}{|c|}{ 2016/2017 growing season } \\
\hline T. harzianum (Th) & $20.75 \pm 0.25 b^{a}$ & 13.5 & $76.50 \pm 0.50 \mathrm{ab}$ & 1.3 \\
\hline T. koningii (Tk) & $18.25 \pm 0.63 c$ & 23.9 & $76.00 \pm 0.41 \mathrm{ab}$ & 1.9 \\
\hline T. virens (Tv) & $17.75 \pm 0.25 c$ & 26.0 & $76.25 \pm 0.25 a b$ & 1.6 \\
\hline$(T h)+(T k)$ & $13.50 \pm 0.29 \mathrm{~d}$ & 43.8 & $72.75 \pm 0.25 c$ & 6.1 \\
\hline$(T h)+(T v)$ & $13.00 \pm 0.41 \mathrm{~d}$ & 45.8 & $74.25 \pm 0.48 \mathrm{bc}$ & 4.2 \\
\hline$(T k)+(T V)$ & $12.75 \pm 0.48 d$ & 46.9 & $71.25 \pm 2.75 c$ & 8.1 \\
\hline$(T h)+(T k)+(T v)$ & $8.25 \pm 0.25 \mathrm{e}$ & 65.6 & $65.50 \pm 0.50 \mathrm{~d}$ & 15.5 \\
\hline Tebuconazole & $7.75 \pm 0.25 \mathrm{e}$ & 67.7 & $54.75 \pm 0.25 \mathrm{e}$ & 29.4 \\
\hline Control & $24.00 \pm 1.35 \mathrm{a}$ & - & $77.50 \pm 0.50 \mathrm{a}$ & - \\
\hline \multicolumn{5}{|c|}{ 2017/2018 growing season } \\
\hline T. harzianum (Th) & $24.00 \pm 0.82 b$ & 49.5 & $85.00 \pm 0.41 \mathrm{a}$ & 1.2 \\
\hline T. koningii (Tk) & $22.50 \pm 0.29 b$ & 52.6 & $85.00 \pm 0.41 \mathrm{a}$ & 1.2 \\
\hline T. virens (TV) & $22.25 \pm 0.48 b$ & 53.2 & $85.00 \pm 0.41 \mathrm{a}$ & 1.2 \\
\hline$(T h)+(T k)$ & $17.25 \pm 0.48 c$ & 63.7 & $78.25 \pm 0.48 b$ & 9.0 \\
\hline$(T h)+(T V)$ & $16.00 \pm 0.71 c$ & 66.3 & $79.50 \pm 0.29 b$ & 7.6 \\
\hline$(T k)+(T V)$ & $17.00 \pm 1.08 \mathrm{c}$ & 64.2 & $78.50 \pm 0.29 b$ & 8.7 \\
\hline$(T h)+(T k)+(T V)$ & $12.25 \pm 0.63 \mathrm{~d}$ & 74.2 & $70.00 \pm 0.41 c$ & 18.6 \\
\hline Tebuconazole & $13.00 \pm 0.58 d$ & 72.6 & $59.25 \pm 0.48 d$ & 31.1 \\
\hline Control & $47.50 \pm 1.19 a$ & - & $86.00 \pm 0.71 \mathrm{a}$ & - \\
\hline
\end{tabular}


Table 5 Effects on peroxidase, polyphenoloxidase, and chitinase enzymes activities of garlic plants under field conditions at 100 days after planting

\begin{tabular}{|c|c|c|c|}
\hline \multirow[t]{2}{*}{ Treatment } & \multicolumn{3}{|c|}{ Enzyme activities in garlic leaves $^{\mathrm{a}}$} \\
\hline & Peroxidase & Polyphenoloxidase & Chitinase \\
\hline \multicolumn{4}{|c|}{ Trial I (40 sclerotia/kg soil) } \\
\hline T. harzianum (Th) & $0.313 \pm 0.005$ de & $0.435 \pm 0.004 d$ & $1.754 \pm 0.014 c$ \\
\hline T. koningii (Tk) & $0.312 \pm 0.006$ de & $0.445 \pm 0.004 \mathrm{~cd}$ & $1.593 \pm 0.021 \mathrm{~d}$ \\
\hline T. virens (Tv) & $0.331 \pm 0.008 \mathrm{~cd}$ & $0.439 \pm 0.003 \mathrm{~cd}$ & $1.515 \pm 0.017 d$ \\
\hline$(T h)+(T k)$ & $0.378 \pm 0.005 b$ & $0.542 \pm 0.009 b$ & $1.909 \pm 0.033 b$ \\
\hline$(T h)+(T v)$ & $0.379 \pm 0.006 b$ & $0.547 \pm 0.003 b$ & $1.921 \pm 0.036 b$ \\
\hline$(T k)+(T V)$ & $0.339 \pm 0.007 c$ & $0.531 \pm 0.005 b$ & $1.900 \pm 0.025 b$ \\
\hline$(T h)+(T k)+(T V)$ & $0.472 \pm 0.004 \mathrm{a}$ & $0.587 \pm 0.002 \mathrm{a}$ & $2.026 \pm 0.046 a$ \\
\hline Tebuconazole & $0.295 \pm 0.019 \mathrm{e}$ & $0.454 \pm 0.014 c$ & $1.386 \pm 0.052 \mathrm{e}$ \\
\hline Control & $0.118 \pm 0.002 f$ & $0.226 \pm 0.004 \mathrm{e}$ & $0.763 \pm 0.022 f$ \\
\hline \multicolumn{4}{|c|}{ Trial II (600 sclerotia/kg soil) } \\
\hline T. harzianum (Th) & $0.339 \pm 0.009 d$ & $0.566 \pm 0.011 \mathrm{e}$ & $1.806 \pm 0.028 d$ \\
\hline T. koningii (Tk) & $0.372 \pm 0.001 c$ & $0.583 \pm 0.005 d$ & $1.933 \pm 0.012 c$ \\
\hline T. virens (TV) & $0.376 \pm 0.005 c$ & $0.566 \pm 0.005 \mathrm{e}$ & $1.918 \pm 0.024 c$ \\
\hline$(T h)+(T k)$ & $0.419 \pm 0.004 b$ & $0.616 \pm 0.004 c$ & $2.198 \pm 0.018 b$ \\
\hline$(T h)+(T V)$ & $0.434 \pm 0.013 b$ & $0.632 \pm 0.006 b$ & $2.193 \pm 0.020 b$ \\
\hline$(T k)+(T v)$ & $0.432 \pm 0.003 b$ & $0.635 \pm 0.004 b$ & $2.172 \pm 0.001 b$ \\
\hline$(T h)+(T k)+(T v)$ & $0.502 \pm 0.004 a$ & $0.659 \pm 0.005 a$ & $2.692 \pm 0.024 a$ \\
\hline Tebuconazole & $0.329 \pm 0.003 d$ & $0.436 \pm 0.003 f$ & $1.457 \pm 0.064 \mathrm{e}$ \\
\hline Control & $0.139 \pm 0.004 \mathrm{e}$ & $0.239 \pm 0.005 \mathrm{~g}$ & $0.786 \pm 0.017 f$ \\
\hline
\end{tabular}

Values are mean of eight replicates for each treatment as well as the control Means \pm standard errors within a column followed by the same letter are not significantly different by Duncan multiple range test at $P<0.05$

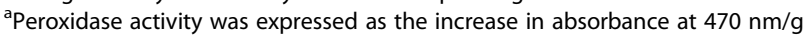
fresh weight/minute. Polyphenoloxidase activity was expressed as the increase in absorbance at $475 \mathrm{~nm} / \mathrm{g}$ fresh weight/minute. Chitinase activity was expressed as $\mathrm{mM} \mathrm{N}$-acetyl glucose amine equivalent released/gram fresh weight $/ 60 \mathrm{~min}$ at $540 \mathrm{~nm}$. Values are means of four replicates

sites followed the same trend but the bulb yield was greater in soil with low inoculum density than with high inoculum density as shown in (Table 7).

\section{Discussion}

In vitro, all Trichoderma species isolates significantly inhibited the growth of S. cepivora (Sc8) in dual culture compared to control (Fig. 1). Obtained results are in harmony with those obtained by Francisco et al. (2011). Trichoderma spp. exert their biocontrol action against fungal phytopathogens either indirectly by competing for nutrients and space or indirectly by mechanisms such as antibiosis and mycoparasitism (Peyghami 2001; Benítez et al. 2004). These results were in agreement with those of Kay and Stewart (1994) and McLean and Stewart (2000), who found strong antagonistic effects of Trichoderma spp. against most pathogenic fungi. They reported that Trichoderma depends on one or more of the following mechanisms: competition for nutrients or space, mycoparasitism or antibiosis, and/or antibiotic excretion. Peyghami (2001) described the mechanism by which $T$. viride and $T$. harzianum affect the pathogen $S$. cepivora via hyphal contact, deformation, and lysis. The three Trichoderma species cultural filtrates decreased S. cepivora sclerotial germination after soaking for $12 \mathrm{~h}$ (Table 2). The present data are in accordance with those obtained by Shalaby et al. (2013), who reported that the percentage of germinated sclerotia soaking in filtrates of T. harzianum and T. koningii were 46.67 and 56.67\%, compared with $93.3 \%$ for control, respectively. This suggests that filtrates of the Trichoderma isolates may contain lytic enzymes or antibiotics, as found by others. McLean and Stewart (2000) and Clarkson et al. (2002) suggested that chitinase, glucanase, and protease produced by antagonistic fungi dissolve pathogen cell walls in certain locations, thus causing substantial damage. Additionally, secretion of antibiotics into filtrates also affects sclerotial germination and growth of soil-borne pathogenic fungi (EL-Kazzaz et al. 2002).

In greenhouse and field experiments, the dual and triple combinations of the tested Trichoderma isolates were more effective than these isolates used individually. Such results are in agreement with the earlier findings of Abd El-Razik et al. (1988). These results also agree with those reported recently by Elshahawy et al. (2017b). Francisco et al. (2011) found that 41 Trichoderma isolates showed excellent levels of antagonism toward S. cepivorum either by competition for nutrients, antibiosis by volatile compounds, or effect of filtering toxins. Shalaby et al. (2013) reported that onion white rot disease incidence was decreased to $29.17 ; 13.89 \%$ and $37.50 ; 11.11 \%$, by the use of T. koningii and T. harzianum, under pots and field experiment, respectively.

Under field conditions, a positive correlation was found between the biocontrol activates of Trichoderma species isolates and enhancement of peroxidase, polyphenoloxidase, and chitinase enzymes in garlic to resist infection with $S$. cepivora. The reduction in garlic white rot disease incidence and severity may be due to an increase in the defense-related enzymes such as peroxidase, polyphenoloxidase, and chitinase. These results are in agreement with those obtained by Sharma et al. (2012). Shalaby et al. (2013) who reported that a close link was found between the biological action of $T$. koningii and T. harzianum and enhancement of the enzyme activities of polyphenol oxidase and peroxidase with ability of onion to resist S. cepivora. The oxidative enzymes play an important role in induced resistance by the oxidation of phenols to oxidized toxic products (quinine) which limit fungal activity. Peroxidases catalyze a number of reactions that fortify plant cell walls. These reactions include the incorporation of phenolics into cell 
Table 6 Effects on plant height, number of leaves/plant, and plant biomass of garlic plants under field conditions at 100 days after planting

\begin{tabular}{|c|c|c|c|}
\hline \multirow[t]{2}{*}{ Treatment } & \multicolumn{3}{|c|}{ Garlic plants grown in field ${ }^{a}$} \\
\hline & Plant height $(\mathrm{cm})$ & Number of leaves/plant & Plant biomass $(\mathrm{g})$ \\
\hline \multicolumn{4}{|c|}{ Trial I (40 sclerotia/kg soil) } \\
\hline T. harzianum (Th) & $69.0 \pm 2.17 b$ & $7.9 \pm 0.13 c$ & $64.95 \pm 2.36 \mathrm{~cd}$ \\
\hline T. koningii (Tk) & $68.4 \pm 1.65 b$ & $7.6 \pm 0.18 \mathrm{~cd}$ & $64.24 \pm 2.58 \mathrm{~d}$ \\
\hline T. virens (Tv) & $68.7 \pm 1.85 b$ & $7.6 \pm 0.18 \mathrm{~cd}$ & $65.63 \pm 2.79 \mathrm{bcd}$ \\
\hline$(T h)+(T k)$ & $75.1 \pm 3.68 \mathrm{a}$ & $8.1 \pm 0.13 b c$ & $70.85 \pm 4.37 \mathrm{bcd}$ \\
\hline$(T h)+(T v)$ & $75.4 \pm 3.60 \mathrm{a}$ & $8.1 \pm 0.23 b c$ & $73.65 \pm 4.98 b$ \\
\hline$(T k)+(T V)$ & $75.7 \pm 3.72 \mathrm{a}$ & $8.6 \pm 0.18 b$ & $73.29 \pm 5.24 b c$ \\
\hline$(T h)+(T k)+(T v)$ & $79.3 \pm 3.61 \mathrm{a}$ & $9.4 \pm 0.18 \mathrm{a}$ & $85.48 \pm 8.66 \mathrm{a}$ \\
\hline Tebuconazole & $61.4 \pm 0.24 c$ & $7.3 \pm 0.16 \mathrm{~d}$ & $54.30 \pm 0.64 \mathrm{e}$ \\
\hline Control & $57.8 \pm 0.71 \mathrm{c}$ & $6.3 \pm 0.25 \mathrm{e}$ & $49.53 \pm 1.06 \mathrm{e}$ \\
\hline \multicolumn{4}{|c|}{ Trial II (600 sclerotia/kg soil) } \\
\hline T. harzianum (Th) & $55.8 \pm 1.89 \mathrm{~cd}$ & $7.1 \pm 0.13 \mathrm{a}$ & $46.40 \pm 1.29 c$ \\
\hline T. koningii (Tk) & $54.8 \pm 2.24 \mathrm{~d}$ & $7.3 \pm 0.16 \mathrm{a}$ & $43.59 \pm 2.13 d$ \\
\hline T. virens (Tv) & $55.7 \pm 1.89 \mathrm{~cd}$ & $7.1 \pm 0.13 \mathrm{a}$ & $46.01 \pm 1.79 c$ \\
\hline$(T h)+(T k)$ & $58.0 \pm 2.40 \mathrm{bc}$ & $7.4 \pm 0.18 \mathrm{a}$ & $50.40 \pm 1.22 b$ \\
\hline$(T h)+(T v)$ & $59.3 \pm 2.51 b$ & $7.6 \pm 0.18 \mathrm{a}$ & $50.41 \pm 1.59 b$ \\
\hline$(T k)+(T v)$ & $59.9 \pm 2.87 b$ & $7.5 \pm 0.19 a$ & $51.23 \pm 1.70 b$ \\
\hline$(T h)+(T k)+(T v)$ & $62.6 \pm 2.81 \mathrm{a}$ & $7.6 \pm 0.18 \mathrm{a}$ & $54.61 \pm 2.41 \mathrm{a}$ \\
\hline Tebuconazole & $45.6 \pm 0.76 \mathrm{e}$ & $6.0 \pm 0.19 b$ & $41.78 \pm 0.65 d$ \\
\hline Control & $39.6 \pm 0.76 f$ & $5.5 \pm 0.19 c$ & $32.40 \pm 0.72 \mathrm{e}$ \\
\hline
\end{tabular}

Means \pm standard errors within a column followed by the same letter are not significantly different by Duncan multiple range test at $P<0.05$

a Values are mean of eight replicates for each treatment as well as the control

walls and lignifications and suberization of plant cell walls. On the other hand, the chitinase enzymes play roles in plant defense against fungi by hydrolyze their cell wall. The amount of them significantly increase and play main role of defense reaction against fungal pathogen by degrading cell wall, because chitin is a major structural component of the cell walls of many pathogenic fungi. Trichoderma application improves plant growth and bulb yield of garlic plants grown under field conditions. In general, the dual and triple Trichoderma isolates combinations were more effective than these isolates used individually (Table 7). These results are in agreement with those obtained by Metcalf et al. (2004). Growth promotion effect is one of the mechanisms of Trichoderma spp. exerted for control of phytopathgenic diseases (Benítez et al. 2004; Sharma et al. 2012; Gajera et al. 2013). The capacity of Trichoderma spp. to promote growth results from the production of phytohormones that promote growth characteristics of the plants. Hexon et al. (2009) described induced production of three auxin-related compounds (indole-3-acetic acid, indole-3-acetaldehyde, and indole-3ethanol) causing development of Arabidopsis seedlings in response to inoculation with $T$. virens and Trichoderma atroviride. This was also supported by Harman et al. (2004) who found that Trichoderma spp. colonize root surfaces and penetrate the epidermis before producing or releasing a variety of compounds that induce localized or systemic resistance responses. Therefore, plants become protected from the pathogenic fungus, indicating induction of SAR in plants treated with the biological isolates.

\section{Conclusion}

White rot caused by S. cepivora is one of the most important diseases of garlic in Egypt. In field experiments, under low (40 sclerotia/ $\mathrm{kg}$ of soil) and high (600 sclerotia/kg of soil) inoculum density, the standard fungicide programme (garlic cloves dipped in tebuconazole plus foliar spray) gave statistically significant disease control compared with the untreated control. Under low disease pressure, significant control, equal to the fungicide treatment, was achieved with the combination of the three Trichoderma spp. biocontrol agents. Reduction of white rot disease was accompanied by increased growth parameters and bulb yield of garlic plants grown under field conditions. However, no antagonistic Trichoderma spp. employed alone gave significant control 
Table 7 Effect of selected Trichoderma strains and their combinations on garlic bulb yield under field conditions

\begin{tabular}{|c|c|c|c|c|}
\hline \multirow[t]{3}{*}{ Treatment } & \multicolumn{4}{|c|}{ Garlic bulb yield (kg/plot) and efficiency of treatment (\%) } \\
\hline & Yield (kg/plot) & Efficiency (\%) & Yield (kg/plot) & Efficiency (\%) \\
\hline & \multicolumn{2}{|c|}{ Trial I (40 sclerotia/kg soil) } & \multicolumn{2}{|c|}{ Trial II (600 sclerotia/kg soil) } \\
\hline \multicolumn{5}{|c|}{ 2016/2017 growing season } \\
\hline T. harzianum (Th) & $26.85 \pm 0.03 a$ & 40.4 & $11.88 \pm 0.03 a$ & 20.6 \\
\hline T. koningii (Tk) & $26.85 \pm 0.03 a$ & 40.4 & $11.80 \pm 0.07 a$ & 20.6 \\
\hline T. virens (Tv) & $26.83 \pm 0.03 a$ & 40.4 & $11.85 \pm 0.03 \mathrm{a}$ & 20.4 \\
\hline$(T h)+(T k)$ & $27.28 \pm 0.05 a$ & 41.3 & $11.85 \pm 0.03 a$ & 20.4 \\
\hline$(T h)+(T v)$ & $27.33 \pm 0.05 a$ & 41.5 & $11.83 \pm 0.03 a$ & 20.3 \\
\hline$(T k)+(T V)$ & $27.38 \pm 0.03 \mathrm{a}$ & 41.6 & $11.88 \pm 0.03 a$ & 20.6 \\
\hline$(T h)+(T k)+(T v)$ & $27.50 \pm 0.00 \mathrm{a}$ & 41.8 & $11.90 \pm 0.00 \mathrm{a}$ & 20.8 \\
\hline Tebuconazole & $20.45 \pm 2.45 b$ & 21.8 & $9.80 \pm 0.11 b$ & 3.8 \\
\hline Control & $16.00 \pm 0.17 c$ & - & $9.43 \pm 0.15 c$ & - \\
\hline \multicolumn{5}{|c|}{ 2017/2018 growing season } \\
\hline T. harzianum (Th) & $21.60 \pm 0.07 c$ & 35.5 & $8.78 \pm 0.06 c$ & 10.3 \\
\hline T. koningii (Tk) & $21.78 \pm 0.03 c$ & 36.0 & $8.90 \pm 0.04 c$ & 11.5 \\
\hline T. virens (TV) & $21.85 \pm 0.32 c$ & 36.2 & $9.13 \pm 0.23 b c$ & 13.7 \\
\hline$(T h)+(T k)$ & $22.65 \pm 0.09 b$ & 38.5 & $9.53 \pm 0.11 \mathrm{ab}$ & 17.3 \\
\hline$(T h)+(T v)$ & $22.60 \pm 0.07 b$ & 38.4 & $9.78 \pm 0.11 \mathrm{a}$ & 19.4 \\
\hline$(T k)+(T v)$ & $22.70 \pm 0.08 b$ & 38.6 & $9.88 \pm 0.09 a$ & 20.2 \\
\hline$(T h)+(T k)+(T v)$ & $23.50 \pm 0.22 \mathrm{a}$ & 40.7 & $9.95 \pm 0.03 \mathrm{a}$ & 20.8 \\
\hline Tebuconazole & $16.00 \pm 0.18 d$ & 12.9 & $8.15 \pm 0.12 d$ & 3.3 \\
\hline Control & $13.93 \pm 0.24 \mathrm{e}$ & - & $7.88 \pm 0.36 d$ & - \\
\hline
\end{tabular}

Values are mean of four replicates for each treatment as well as the control

${ }^{\mathrm{a}}$ Means \pm standard errors within a column followed by the same letter are not significantly different by Duncan multiple range test at $P<0.05$

of white rot under high disease pressure. It was concluded that, at the low disease pressure site, the low level of inoculum and disease incidence enabled the three biocontrol agents to bring about disease control that were related to improve garlic growth and production.

\section{Acknowledgements}

The authors thank The Affairs of Research Projects, National Research Centre, for funding this research program under Grant no. 11030137.

\section{Funding}

National Research Centre.

\section{Availability of data and materials}

The datasets used and/or analyzed during the current study are available from the corresponding author on reasonable request.

\section{Authors' contributions}

All authors read and approved the final manuscript.

\section{Ethics approval and consent to participate}

Not applicable.

\section{Consent for publication}

Not applicable.

\section{Competing interests}

The authors declare that they have no competing interests.

\section{Publisher's Note}

Springer Nature remains neutral with regard to jurisdictional claims in published maps and institutional affiliations.

Received: 16 December 2018 Accepted: 28 January 2019 Published online: 12 February 2019

\section{References}

Abd El-Moity TH (1976) Studies on the biological control of white rot disease of onion. MSc Dissertation, Faculty of Agric Menofia University Egypt, p 122

Abd El-Razik AA, El-Shabrawy AM, Amin AM, Abd-El-Rahim MHA (1988) Effectiveness of certain fungi and bacteria associated with sclerotia of Sclerotium cepivorum in upper Egypt soil in controlling white rot of onion. Egyptian J Phytopathology 7:107-114

Abd El-Razik AA, Shatla MN, Rushdi M (1973) Studies on the infection of onion plants by Sclerotium cepivorum Berk. Phytopathol Z 76:108-116

Abd-El-Moity TH, Shatla MN (1981) Biological control of white rot disease of onion (Sclerotium cepivorum) by Trichoderma harzianum. Phytopathol Z 100:29-35

Anonymous (2017) Bulletin of the agricultural statistics, 2nd edn. Ministry of Agriculture and Land Reclamation, Egypt, p 530

Bashan Y, Okon Y, Henis Y (1985) Peroxidase, polyphenol oxidase, and phenols in relation to resistance against 214 Pseudomonas syringae pv. tomato in tomato plants. Can J Bot 65:366-372

Bell DK, Wells HD, Markham CR (1982) In vitro antagonism of Trichoderma species against six fungal plant pathogens. Phytopathology 72:382-379

Benítez T, Rincón AM, Limón MC, Codón AC (2004) Biocontrol mechanisms of Trichoderma strains. Int Microbiol 7:249-260

Clarkson JP, Payne T, Mead A, Whipps JM (2002) Selection of fungal biological control agents of Sclerotium cepivorum for control of white rot by sclerotial degradation in a UK soil. Plant Pathol 51:735-745 
Coley-Smith JR (1960) Studies of the biology of Sclerotium cepivorum Berk. IV. Germination of sclerotia. Ann Appl Biol 48:8-18

Coley-Smith JR (1990) White rot disease of Allium: problems of soil-borne diseases in microcosm. Plant Pathol 39:214-222

Coventry E, Noble R, Mead A, Whipps JM (2002) Control of white rot (Sclerotium cepivorum) with coopted garlic waste. J Soil Biochem 34:1037-1045

Crowe F (1995) White rot. In: Schwartz HF, Mohan SK (eds) Compendium of onion and garlic diseases. The American Phytopathological Society, Minnesota, pp 14-16

De Oliveira VL, De M, Bellei M, Borges AC (1984) Control of white rot of garlic by antagonistic fungi under controlled environmental conditions. Can J Microbiol 30:884-889

Dilbo C, Alemu M, Lencho A, Hunduma T (2015) Integrated management of garlic white rot (Sclerotium cepivorum Berk) using some fungicides and antifungal Trichoderma species. J Plant Pathol Microb 6:251. https://doi.org/ 10.4172/2157-7471.1000251

El-Kazzaz MK, Ghoniem KE, Hammond Sahar MR (2002) In vitro effects of some bacterial and fungal antagonists on certain soilborne fungi isolated from diseased tomato and pepper plants. J Agric Res Tanta Univ 28:9-22

El-khateeb NMM (2004) Pathological studies on Sclerotium cepivorum the causal agent of onion white rot and its control by biological agents. MSC Dissertation, Faculty of Agric Kafr E1-Sheikh Tanta Univ Egypt

Elshahawy IE, Saied N, Abd-El-Kareem F, Morsy A (2017b) Biocontrol of onion white rot by application of Trichoderma species formulated on wheat bran powder. Arch Phytopathol Plant Protect 50(3-4):150-166

Elshahawy IE, Saied N, Abd-El-Kareem F, Morsy A (2017c) Field application of sclerotial mycoparasites as biocontrol agents to Stromatinia cepivora, the cause of onion white rot. J Plant Pathol 99(2):391-401

Elshahawy IE, Saied N, Abd-El-Kareem F, Morsy A (2018) Field application of selected bacterial strains and their combinations for controlling onion and garlic white rot disease caused by Stromatinia cepivora. J Plant Pathol 99(2): $391-401$

Elshahawy IE, Saied NM, Morsy AA (2017a) Fusarium proliferatum, the main cause of clove rot during storage, reduces clove germination and causes wilt of established garlic plants. J Plant Pathol 99(1):81-89

El-Sheshtawi M, El-Gazzar T, Saad AS (2009) Comparative study between chemical and non-chemical control against Sclerotium cepivorum, the causal white rot of onion under Egyptian condition. J Agric Sci Mansoura Univ 34:2169-2182

Entwistle AR (1983) Changes in the effectiveness of iprodione for the control of Allium white rot. Phytopathology 73:800 (abstract only)

Entwistle AR (1992) Controlling Allium white rot (Sclerotium cepivorum) without chemicals. Phytoparasitica 20:1215-1255

Entwistle AR, Munasinghe HL (1980) The effect of iprodione on sclerotium germination, root infection and mycelial spread of Sclerotium cepivorum in salad onions. Ann Appl Biol 95:329-339

Francisco DH, Angelica MP, Gabriel M, Melchor CS, Raul R, Cristobal N, Francisco CR (2011) In vitro antagonist action of Trichoderma strains against Sclerotium sclerotiorum and Sclerotium cepivorum. Am J Agric Biol Sci 6(3):410-417

Gajera H, Domadiya R, Patel S, Kapopara M, Golakiya B (2013) Molecular mechanism of Trichoderma as bio-control agents against phytopathogen system - a review. Curr Res Microbiol Biotechnol 1:133-142

Hammerschmidt R, Lamport DTA, Muldoon EP (1984) Cell wall hydroxyproline enhancement and lignin deposition as an early event in the resistance of cucumber to Cladosporium cucumerinum. Physiol Plant Pathol 24:43-47

Harman GE, Howell CR, Vitrbo A, Chet I, Lorito M (2004) Trichoderma speciesopportunistic, virulent plant symbionts. Nat Rev Microbiol 2:43-56

Harrison YA, Stewart A (1988) Selection of fungal antagonists for biological control of onion white rot in New Zealand. N Z J Exp Agric 16(3):249-256

Hexon C, Macias-Rodriguez L, Cortes-Penagos C, López-Bucio J (2009) Trichoderma virens, a plant beneficial fungus, enhances biomass production and promotes lateral root growth through an auxin-dependent mechanism in Arabidopsis. Plant Physiol 149:1579-1592

Hovius MHY, McDonald MR (2002) Management of Allium white rot [Sclerotium cepivorum] in onions on organic soil with soil applied diallyl disulfide and di-N-propyl disulfide. Can J Plant Pathol 24:281-286

Kay SJ, Stewart A (1994) Evaluation of fungal antagonists for control of onion white rot in soil box trials. Plant Pathol 43:371-377

Lee NT (1973) On extraction and quantitation of plant peroxidase enzymes. Physiol Plant 29:198-203

Mahdizadehnaraghi R, Heydari A, Zamanizadeh HR, Rezaee S, Nikan J (2015) Biological control of garlic (Allium) white rot disease using antagonistic fungi-based bioformulations. J of Plant Protection Res 55(2):136-141
McLean KL, Braithwaite M, Swaminathan J, Stewart A (2012) Variability in control of onion white rot by Trichoderma atroviride under different disease pressures. Australas Plant Pathol 41:341-346

McLean KL, Stewart A (2000) Application strategies for control of onion white rot by fungal antagonists. N Z J Crop Hortic Sci 28:115-122

McLean KL, Swaminathan J, Frampton CM, Hunt JS, Ridgway HJ, Stewart A (2005) Effect of formulation on the rhizosphere competence and biocontrol ability of Trichoderma atroviride C52. Plant Pathol 54:212-218

Metcalf DA, Dennis JJC, Wilson CR (2004) Effect of inoculum density of Sclerotium cepivorum on the ability of Trichoderma koningii to suppress white rot of onion. Plant Dis 88(3):287-291

Monreal J, Reese ET (1969) The chitinase of Serratia marcescens. Can J Microbiol 15:689-696

Palmero DL, Galvez LP, Garcia MD, Gil JS, Benito SS (2013) The effects of storage duration, temperature and cultivar on the severity of garlic clove rot caused by Fusarium proliferatum. Postharvest Biol Technol 78:34-39

Peyghami E (2001) Antagonistic effects of several isolates of Trichoderma on fungi causing onion root rot, East Azarbaidjan Province. Iran J Agric Sci 32: $747-755$

Pinto CMF, Mafia LA, Casali WWD, Berger RD, Cardoso AA (2000) Production components and yield losses of garlic cultivars planted at different times in a field naturally infested with Sclerotium cepivorum. Int J Pest Manage 46:67-72

Rifai MA (1969) A revision of the genus Trichoderma. Mycological papers no. 116. Commonwealth Mycological Institute, Kew, Surrey

Shalaby ME, Ghoniem KE, El-Diehi MA (2013) Biological and fungicidal antagonism of Sclerotium cepivorum for controlling onion white rot disease. Ann Microbiol 63:1579-1589

Sharma R, Joshi A, Dhaker RC (2012) A brief review on mechanism of Trichoderma fungus use as biological control agents. Int J Innov Bio-Sciences 2:200-210

Slade EA, Fullerton RA, Stewart A, Young H (1992) Degradation of the dicarboximide fungicides iprodione, vinclozolin and procymidone in Patumahoe clay loam soil, New Zealand. Pestic Sci 35:95-100

Stewart A, McLean KL (2007) Biological control of onion white rot. Chapter 6 in Biological control of plant diseases. The Haworth Press, Inc, New York, pp 123-148

Tamire Z, Chemeda F, Parshotum PK, Sakhuja PK, Ahmed S (2007) Association of white rot (Sclerotium cepivorum) of garlic with environmental factors and cultural practices in the north Shewa highlands of Ethiopia. J Crop Prot 26: 1566-1577

Ulacio-Osorio D, Zavaleta-Mejía E, Martínez-Garza A, Pedroza-Sandoval A (2006) Strategies for management of Sclerotium cepivorum Berk in garlic. J Plant Pathol 88:253-261

Utkhede RS, Rahe JE (1979) Wet sieving flotation technique for isolation of sclerotia of Sclerotium cepivorum from muck soil. Phytopathology 69:295-297

Utkhede RS, Rahe JE (1980) Biological control of onion white rot. Soil Biol Biochem 12:101-104

Walker A, Brown PA, Entwistle AR (1986) Enhanced degradation of iprodione and vinclozolin in soil. Pestic Sci 17:183-193

Watanabe T (1994) Pictorial atlas of soil and seed fungi. Morphologies of cultured fungi and key to species. Lewis, Boca Raton

Wood RJ (1980) Control of onion white rot with iprodione., Proceedings of the 33rd New Zealand Weed and Pest Control Conference, pp 203-205

Zeray S, Mohammed Y (2013) Searching and evaluating of cost effective management options of garlic white rot (Sclerotium cepivorum Berk) in Tigray, Northern Ethiopia. J Plant Pathol Microb 4:189

Zewide T, Fininsa C, Sakhuja PK (2007) Management of white rot (Sclerotium cepivorum) of garlic using fungicides in Ethiopia. Crop Prot 26:856-866 